\title{
Relationship between Organizational Climate, Employee Psychological Empowerment, and Innovation in Market Research Firms in Kenya
}

\author{
James Wangombe ${ }^{1}$, Tecle H. Yohannes ${ }^{2}$ \\ ${ }^{1}$ Department of Entrepreneurship, Technology, Leadership and Management, Jomo Kenyatta University of Agriculture \\ and Technology, P. O. Box 62000-00200, Nairobi-Kenya, Human Resources Director - SBO Research Ltd Firm, Kenya \\ ${ }^{2}$ Rabenstraße 31, 25421 Pinneberg, Germany \\ Correspondence: Dr. Habtemariam, Rabenstraße 31, 25421 Pinneberg, Germany
}

Received: September 19, 2017

Accepted: October 20, 2017

Available online: October 23, 2017

doi:10.11114/afa.v4i1.2723

URL: https://doi.org/10.11114/afa.v4i1.2723

\begin{abstract}
The purpose of the study was to find out the relationship between Organizational Climate (OC), Employee Psychological Empowerment (EPE) and innovation in Market and Social Research Firms (MSRFs) in Kenya. This was motivated by inconsistent empirical findings of the previous scholars on the effect of organizational climate on innovation. Besides, it was inspired by the omission of the employee psychological empowerment as intervening variable between OC and innovation. This study therefore, investigated the effect of OC on EPE and EPE on innovation. Further, direct effect of OC on innovation was also assessed. To address these objectives, this study used cross-sectional research design. The data was collected using a structured questionnaire and analyzed using Structural Equation Modelling (SEM). The study found the effect of training support on EPE and innovation was positive but insignificant while work place support on EPE had partial effect but insignificant effect on innovation. However, transformational leadership was found to be significant on both EPE and innovation. Further, the EPE had partial mediating effect between leadership and innovation. The findings offer more insights to the theorists of intrinsic motivation that intrinsic motivation taps on some organizational climate factors to promote innovation. The results could be helpful to human resources practitioners and policy makers when deciding on a mix of organizational climate factors to promote innovation in institutions. Consideration of multiple organizational factors as opposed to a single factor to enhance innovation at micro level in their work place is hinted.
\end{abstract}

Keywords: organizational climate, employee psychological empowerment and innovation

\section{Introduction}

The $21^{\text {st }}$ century global business environment is bedevilled with fast changing technology, growing volatility, global competition, organization change, social conflicts, environmental degradation and high rate of unemployment among others (George \& Zhou, 2007; Runco, 2004). To overcome these challenges, nations and organizations need to hire creative and innovative employees (Eustace \& Martins, 2014). This is because innovation has been found to be one of the most critical tools in today's fast changing environment that can enable nations, organizations, change managers, employees and society to overcome the many challenges and enhance the common good of the society (George \& Zhou, 2007; Batey, 2012).

However, most organizations consider innovation from a financial perspective and at a strategic level, neglecting other factors at micro level which too have an impact on the innovation. Among such factors include organizational climate factors and innovation at employee level. This is a fact supported by Spreitzer (1995) who on their part argued that organizational climate factors can positively influence level of innovation in organizations, but are inadequate in the absence of psychological empowerment of employees and their managers. This area hence, has attracted scholars with an aim to study, understand and document the relationship between organizational climate and innovation at the workplace. In the verge of this, scholars have used different measurements, some based on outcomes, others based on levels of operations, while others based on different rating styles, different models, and different techniques of data analyses (Amabile, 1996, Furnham et al., 2008; Kaufaman, Plucker \& Baer, 2008; Mumford, 2003; Runco, 2004; Alice, 2011).

Use of different models and different number of questions in the instrument used by different scholars has resulted in inconsistent findings on the relationship between organizational climate and innovation (Hunter et.al., 2004). For example, Hsiu (2007) found inverted U-shape relationship, Ndanuko (2012) found a positive significant relationship while Purohit 
and Wadhwa, (2012) found a negative association. These inconsistent results caused Boso, Cadogan, and Story (2013), Mumford (2003) and Hunter, Bedell, and Mumford (2007) to argue that the inconsistency could be due to something else unknown yet.

Wanberg and Banas (2000) posited that certain organizational climate factors combined with other micro factors can resolve this inconsistency. This was complimented by Alice and Steven (2016) and Furnham, Batey, and Manfield, (2008) who by focusing on employee psychological empowerment, found out that it stimulates innovation by providing employees with social, emotional and technical support needed to influence innovation. But even with such insight, the few researchers who attempted to study the influence of psychological empowerment on innovation, have focused on managers alone leaving out the lower cadre staff (Nijstand \& Stroebe, 2006; Choi \& Thompson, 2006). This has not solved the problem of inconsistency on outcomes but have left the scholars divided on the outcomes of influences of organizational climate to innovation. This has left organizations unaware of organizational climate variables to focus on if they aim at yielding high levels of innovations (Muturi, Ochieng \& Douglas, 2015). It is on this premise that this study considered a model with some omitted OC variables mediated by EPE at employees' level to find out the influence they have on innovation in the service sectors which have not been researched before. This study further documents and compliments the OC theories.

This study therefore, considered employees rating of organizational climate variables that included supervisor support, training support, co-worker support, leadership and employee psychological empowerment indicated by meaning, competence, impact, and self-determination as the mediating variable between $\mathrm{OC}$ and innovation. Innovation was measured by idea generation and implementation. Since most of the previous analytical methodology applied were correlation and regression analyses which did not resolved the inconsistency, this study progressively applied structural equation modelling technique to analyze these multiple relationships in order to improve the accuracy in the effort to further improve the results.

\section{Literature Review}

\subsection{Concept of Organizational Climate}

This is the perceptions or feelings of employees about their working environment (organizational climate) and characteristics of certain employees within the environment such as supervisors and leaders (Amabile, 1996; Ekvall, 1996; Dul \& Ceylan, 2011). Such feelings influence behaviours and attitudes of employees to innovate or not to. If these organizational climate factors and individual characteristics are assessed, they can help estimate the level of innovation existing and propose interventions to improve it (Dodd, Smith, \& Wards, 2002). According to Amabile (1996) and, Dul and Ceylun (2011) the perception of working environment and characteristics of certain individuals within the environment such as supervisors and leaders can either promote or inhibit the level of innovation. On their part, Nystrom, Ramamurthy and Wilson (2002) posited that organizational climate dimensions, size and resources combined positively promote innovation. An organizational climate perceived to allow employees to access information on organizational vision and individual performance was found to improve level of innovation (Speitzer, 1995). In furtherance to assessment of how organizational climate factors influence innovation, some scholars focused on organizational formal rules and structures as organizational climate dimensions and reported that the two factors can positively influence level of innovation in organizations, but are inadequate in the absence of psychological empowerment of employees and their managers (Spreitzer, 1995).

\subsection{Concept of Employee Psychological Empowerment}

Psychological empowerment is the motivational concept of self-efficacy. It is an intrinsic task motivation exemplified by four cognitive elements. These include meaning, impact, competence, and self-determination. Meaning describes the value of a work goal or purpose, judged in regard to an employee's own ideals or standards (Thomas \& Velthouse, 1990). Meaning is the fit between the work requirements, role, beliefs, values, and behaviors (Brief \& Nord, 1990; Hackman \& Oldham, 1980) as cited in Spreitzer (1995). Competence refers to employee's self-efficacy in regard to belief and capability to perform activities with skill he/she has (Gist, 1987). It is the personal mastery, or effort-performance expectancy (Bandura, 1989). Self-determination on its part is the individual's sense of having choice in initiating and regulating actions (Deci, Connell, \& Ryan, 1989). Self-determination reflects freedom in the initiation and continuation of work behaviours and processes about work methods, pace, and effort (Bell \& Staw, 1989) as cited Spreitzer (1995). Impact is the degree to which an employee can influence strategic, administrative, or operating outcomes at workplace (Ashforth, 1989). The four dimensions are argued to combine additively to create an overall construct of psychological empowerment which further enhance creativity and innovation. If one of these variables is missing, less empowerment is felt, though not completely eliminated. Empowerment is not an enduring personality trait generalizable across situations, but rather, a set of cognitions shaped by a work environment (Thomas \& Velthouse, 1990). Empowerment reflects people's perceptions about themselves in relation to their work environments (Bandura, 1989). It is a continuous variable; people can be viewed as more or less empowered, rather than empowered or not empowered. Finally, empowerment is not 
a global construct generalizable across different life situations and roles but rather, specific to the work, which is unique across organizations.

When employees enjoy support of their organizational members they develop a sense of positive psychological conditions ideal for innovation. Employee empowerment has been found to have a positive effect on trust, innovation and organizational performance (Berraies, Chaher, \& Yahia, 2014).

\subsection{The Concept of Innovation}

Creativity and innovation constructs are reported to be closely related and significantly overlap in terms of characteristics (Angle, 1989). In contrast, creativity is the generation of novel and useful ideas, primarily at the macro level (Amabile, 1996). Innovation on its part is the process by which these ideas are captured, filtered, funded, developed, modified, clarified, and eventually commercialized and/or implemented. Creativity is the precursor of innovation. In order for an organization to remain relevant and competitive in pursuit of its purpose, leadership must pay attention to both ends of the process, generating creative ideas frequently and utilizing its innovation process to realize the potential value of those ideas.

This growing importance of creativity and innovation portends the need for identifying those factors that promote or stifle creativity and innovation to solve the many global and organizational challenges experienced in this century (Eustace \& Martins, 2014). This has resulted to many studies proliferating focusing on different interests and approaches in trying to identify those factors that influence creativity and innovation as well as understanding more about the two constructs (Govindarajan \& Trimble, 2010). Some scholars interested in this area, have focused on innovation on the premise of problem solving ability of the generated ideas (Govindarajan \& Trimble, 2010). In all the studies, researchers have concurred that innovation is very critical for solving the global and organizational challenges sustainably (Dul \& Ceylun, 2011; Nystrom, Ramamurthy \& Wilson, 2002).

Although researchers have concurred that innovation is very critical for any organization, nations, society, change managers, scholars, individual development and change, organizations on their part have found it difficult to maintain high level of employee innovation in organizations (Shalley et al., 2009; Shalley et al., 2004; Shin \& Zhou, 2003). To address the issue of low level of employee innovation in organizations, scholars have identified several factors that may influence innovation (Amabile \& Khaire, 2008). Among the factors identified that can stimulate innovation is the perception or feeling employees form about the working environment and characteristics of certain employees within the environment such as supervisors and leaders (Amabile, 1996; Dul \& Ceylun, 2011). If these organizational climate factors and individual characteristics are assessed, they can help estimate the level of innovation existing and propose interventions to improve it (Dodd et al., 2002).

\subsection{Theoretical Review}

Organizational climate and innovations are constructs that have continued to attract many scholars in the last fifty years of study. This has therefore culminated to the development theories around them in the verge of understanding the constructs as management tools in a fast-changing environment. Organizational climate theories explained in general the effects of various organizational variables to the business outcome of creativity and innovation. Contingency and organizational learning theories proliferated around organizational climate. Intrinsic motivation theory was evaluated on basis of employee empowerment to deliver innovation and majorly explained the constructs of training in the organizational climate among other variables. Leadership theories on the same breath emerged to explain and demonstrate the influence of leadership has on various business outcomes among them creativity and innovation. This research particularly focused on transformational leadership theory to explain the leadership influence as an organizational climate factor on employee empowerment and innovation in businesses.

\subsubsection{Intrinsic Motivation Theories}

The theory states that an individual is intrinsically motivated to behave in a certain way when he feels internally rewarded by the behavior chosen (Deci \& Ryan, 1985). To be creative and innovative on products, processes and services, individuals must feel internally motivated and rewarded. Intrinsic motivation is driven by competence, relatedness and autonomy. It is also shaped externally by recognition, reward, co-operation, autonomy and curiosity. The challenge now is how the owners of the business can create an ideal climate to intrinsically promote continuous innovation which is rewarding, challenging and interesting to all individuals. The two authors look at the leader as the person responsible for this kind of climate and this has motivated the researcher to consider leadership as an organizational climate factor that can influence employee psychological empowerment to promote innovation which from the reviewed literature has rarely been applied in this perspective before.

\subsubsection{Transformational Leadership Theory}

Burns (1978) is said to be the proponent of this theory. The theory states that a transformational leader creates high 
performance team who deliver value through high level of morality and motivation. This kind of leadership is a process found in all levels of the business, teams, departments, divisions and organization as a whole. This leadership demonstrates a visionary, inspiring, daring, risk taking and challenging mind-set on all the activities of the business. These are ideal characteristics for the business to try new thing to survive and grow (innovation). These leaders are said to deliver change in organizations. These leaders possess inspirational motivation, intellectual stimulation, idealized influence and individualized consideration ideal for creativity and innovation (Burns, 1978). This leadership encourages new ideas from workers and allows them to make and learn from mistakes. They challenge the inefficient processes and discard them. They mentor followers and reward them for creativity and innovation. They allow follower to make decisions and support them to implement their ideas (Bass, 1985). This leadership uses social and spiritual values to influence followers. Transformational leaders are far looking for the survival of the business, emphasizes co-operation, ethics and community value add. It is a leadership said to be critical to the proper functioning of the society and social institutions (Antonakis \& Sternberg, 2004). This makes this leadership preferred from transactional leadership which is said to be selfish and not short-lived. This leadership is measurable in terms of the leader influence to the followers and can be used to predict their behaviour and performance outcomes (Bass,1985). The proponent of the new Instrumental leadership postulate that although unique and goes beyond transformational leadership, it was proposed to foster Transformational leadership activities (Antonakis \& House, 2014). Critics of transformational leadership assert that it is a self-promotional leadership that is hard to train and teach. Followers are likely to be manipulated by transformational leaders. They also claim that it is not ideal in stable business environments and on less educated/trained workforce which is the kind of environment facing 21 st century businesses.

\subsubsection{Componential Theory of Creativity and Innovation}

The componential theory of creativity proposed by Amabile (1994) is founded on social and psychological components critical for individuals to be eliciting creative products or solutions. The theory bases its definition of creativity as the production of ideas or outcomes that are both novel and appropriate to some goals. This theory encompasses organizational creativity and innovation, with the effect of the work environments created by managers in organizations. The size of creativity that an individual produce at any given point is a function of the creativity components operating, at that time, within and around that person.

The theory is grounded on the premise that innovation is a deliberate introduction and application within a role, group or organization, ideas, processes, products or procedures, new to the particular department of adoption, started with a view to significantly benefit the individual, the team, the organization or the wider society. For organizations to survive and be sustainable, innovation and creativity must be accelerated. The theory postulates that creativity and innovation is dependent on the level of expertise (skills, training and knowledge), environment he/she is operating in particularly social environment (Personality) and the intrinsic motivation. Support of innovation by the leaders is critical for high level of creativity and innovation.

A weakness of this theory is that control of what to innovate is needed because not all innovations and creativities are beneficial (Hunter et.al., 2007). The theory takes human beings as the parameter for innovation rather than profit or outcomes. The theory stipulates that innovation of a person is dependent on the judgment of others. Innovation, which is taken to mean commercialization of creativities, can have both impersonal and interpersonal processes of social comparison and judgment. This assumption overlooks that small innovation can also be important in the process. Creativity is majorly associated with individuals, while innovation implementation is taken to be accomplished by groups, organization or societies.

\subsection{Empirical Review}

\subsubsection{Effect of Organizational Climate and Employee Psychological Empowerment on Innovation}

Psychological perspective, empowerment is defined as a psychological state that is linked to increased intrinsic task motivation based on an employee's sense of self-determination, meaning, impact and competence (Thomas \& Velthouse, 1990) as cited by Berraies, Chaher, and Yahia (2014). Employees themselves must psychologically feel that they have power to act and to perform a task. According to Nyhan, (2000) and Kahreh and Heidar (2011), empowerment is understood as the freedom or autonomy and the authority bestowed on the employees to execute and control their tasks to the best of their abilities. The psychological condition being recognized as an important state or condition at work. Individuals have a primary motive to seek meaning in their work which occurs when individuals feel useful and valuable and that they are making a difference. High quality co-worker interactions create a sense of belonging, a strong sense of social identity and meaning. Loss of social identity can lead to meaninglessness. When an employee feels support from the supervisor and the co-workers at work he is likely to experience psychological meaningfulness at work as support engenders feelings of being worthy, useful, and valued, that the person is making a unique contribution and is not taken for granted (Khan, 1997) cited by Arora and Kamalanabhan (2013). It is proposed that the support felt from the supervisor and the co-workers lead to sense of psychological meaningfulness at work. Prior research has shown that support from the 
supervisor and co-workers may be an important precursor to innovation through their impact on psychological empowerment of meaningfulness, safety and availability. It has also been found that psychological conditions foster employee engagement in particular work behaviours through intrinsic motivation (Carmeli \& Spreitzer, 2009). Brunetto, Farr-Wharton, and Shacklock (2007) argued that empowerment strengthens organizational trust which emanate from leadership and this further result to high level of innovation. Jafari and Iranzadeh, (2013) asserted that employees, who makes self-determined choice about their day to day activities, are likely to be more effective and efficient than non-empowered employees. Managers must therefore create an organizational climate that promotes the development of capabilities required to innovate. The management literature has reported that some managerial practices support capabilities development and have a positive effect on innovation. According to Khan (1997), empowerment strengthens trust between employees and leaders. Nyhan (2000) posited that empowerment contributes to the development of interpersonal trust especially between employees and supervisors. Berraies, Chaher, and Yahia, (2014 on their part showed that there is a significant relationship between empowerment and employees' trust in their colleagues, in their superiors and in organization. Moye and Henkin (2006) emphasized also that empowerment is perceived by employees as a pointer that their leaders trust them. According to these authors, this would lead them in turn to trust their managers which is an ideal climate for innovation.

\subsubsection{Psychological Empowerment and Innovation}

When employees enjoy support of their organizational members they develop a sense of positive psychological conditions ideal for innovation. Employee empowerment has been found to have a positive effect on trust, innovation and organizational performance (Berraies, Chaher, \& Yahia, 2014). Researchers have pointed out that employee empowerment is a critical factor for innovation (Brunetto Farr-Wharton, \& Shacklock, 2007; Ertürk, 2012; Fernandez \& Moldogaziev, 2013). Such empowerment motivates employees to share their innovative ideas and use their skills in order for organizational success. Some researchers reported positive link between empowerment and innovation (Çakar \& Ertürk, 2010; Ertürk, 2012; Helms, 2006; Muindi, 2011) while others found a negative relationship or instead no significant link between these variables. Kmieciak et al. (2012), in his study concluded that empowerment did not affect the company's ability to innovate. A study by Jung et al. (2003) revealed that this managerial practice has a negative effect on organizational innovation. In the light of such contradictory results, it could be interesting to identify variables that may be included to strengthen employee psychological empowerment to mediate the relationship between organizational climate, leadership and innovation. Brunetto and Farr-Wharton, and Shacklock (2007) argued that empowerment strengthens organizational trust which emanate from leadership.

\section{Methods}

\subsection{Introduction}

This study was conducted in Marketing and Social Research Association (MSRA) firms in Kenya. These marketing research firms operate across African countries only. According to the annual report of MSRA (2013) penetrating into new market, especially to the western countries is a key challenge due to lack of access to recent technology such as computerized data collection, slow rate of adoption of online research, access to new sophisticated and affordable software, poor collaboration among the firms, high cost of operations, inefficient resources (HR and capital resources), high competition and lack of standardized quality control. These and other unforeseen challenges affect their performance negatively yet little focus has been given to these firms. Hence, this study focused on the role of organizational climate on innovation because innovation of the individual employees might be one of the avenues to minimize these challenges and to improve innovation which further leads to higher performance. Therefore, this research is conducted in MSRA for two reasons. The first reason was that to find out a way to increase innovations of MSRFs to minimize the existing challenges. The second reason was that to test the relationship between OC, EPE, and innovation which were not yet tested in research firms, particularly in Kenya. These two major issues inspired us to conduct this research in MSRA.

This study adopted a cross-sectional survey research design because it facilitated the collection of data from the employees of many different firms in one industry at one point in time (Kerlinger, 2007). The population of the study consisted of all the employees in the marketing research firms in Nairobi because most of these MSRA firms are domiciled in Nairobi.

\subsection{Sample Size}

The sample size is determined by the unit of analysis, types of analysis, types of data, margin of error, size of population and variance of the population. The sample size for this study was estimated using two statistical formula developed by Bartlett, Kotrlik and Higgins (2001) and Jackson (2003) respectively as presented below.

Bartlett et al. (2001) provided a statistical table to determine the minimum acceptable sample size for a given population size for continuous and categorical data as depicted in Table 3.1. The nature of data for this study was continuous (because of five-point scale as the primary variable of measure) and the population size was 4000 . Therefore, the minimum sample 
size for multiple regression and factor analysis based on this statistical tool was 198 at alpha $=0.01, \mathrm{t}=2.58$ and margin of error $=0.03$. Is this sample size adequate for structural equation modelling?

Table 3.1. Table for determining minimum acceptable sample size for a given population size for continuous and categorical data

\begin{tabular}{|c|c|c|c|c|c|c|c|}
\hline & \multicolumn{3}{|c|}{ Continuous data (margin of error $=.03$ ) } & \multicolumn{4}{|c|}{ Categorical data (margin of error $=.05$ ) } \\
\hline Population size & $\begin{array}{l}\text { Alpha } \\
\mathrm{t}=1.65\end{array}$ & $\begin{array}{l}\text { alpha }=.05, \mathrm{t}= \\
1.96\end{array}$ & $\begin{array}{l}\text { alpha }=.01, \mathrm{t}= \\
2.58\end{array}$ & $\underset{t=1.65}{\text { alpha }}=.50$ & $\begin{array}{l}\text { alpha }=.50, \mathrm{t}= \\
1.96\end{array}$ & $\begin{array}{l}\text { alpha } \\
\mathrm{t}=2.58\end{array}$ & $=.50$, \\
\hline 100 & 46 & 55 & 68 & 74 & 80 & 87 & \\
\hline 200 & 59 & 75 & 102 & 116 & 132 & 154 & \\
\hline 300 & 65 & 85 & 123 & 143 & 169 & 207 & \\
\hline 400 & 69 & 92 & 137 & 162 & 196 & 250 & \\
\hline 500 & 72 & 96 & 147 & 176 & 218 & 286 & \\
\hline 600 & 73 & 100 & 155 & 187 & 235 & 316 & \\
\hline 700 & 75 & 102 & 161 & 196 & 249 & 341 & \\
\hline 800 & 76 & 104 & 166 & 203 & 260 & 363 & \\
\hline 900 & 76 & 105 & 170 & 209 & 270 & 382 & \\
\hline 1,000 & 77 & 106 & 173 & 213 & 278 & 399 & \\
\hline 1,500 & 79 & 110 & 183 & 230 & 306 & 461 & \\
\hline 2,000 & 83 & 112 & 189 & 239 & 232 & 499 & \\
\hline 4,000 & 83 & 119 & 198 & 254 & 351 & 570 & \\
\hline 6,000 & 83 & 119 & 209 & 259 & 362 & 598 & \\
\hline 8,000 & 83 & 119 & 209 & 262 & 367 & 613 & \\
\hline 10,000 & 83 & 119 & 209 & 264 & 370 & 623 & \\
\hline
\end{tabular}

Source: Bartlett, Kotrlik, and Higgins (2001)

The sample size for structural equation modelling was developed by Jackson (2003). His sample size formula was applicable when the estimation method was maximum likelihood. In maximum likelihood estimation, Jackson (2003) suggested that researchers think about minimum sample size in terms of the ratio of cases $(\mathrm{N})$ to the number of model parameters that require statistical estimates (q). According to Jackson (2003), an ideal sample size-to-parameters ratio would be 20:1. Less ideal would be an $\mathrm{N}$ : q ratio of 10:1. As the $\mathrm{N}$ : q ratio decreases below 10:1 (e.g. 5:1), so does the trustworthiness of the results.

The model parameters that require statistical estimation for this study were 83 parameters, which was calculated from the formula $\mathrm{q}=\Theta+\Lambda+\Phi+\Psi+\Gamma+\mathrm{B}=29+29+6+6+11+2=83$. However, there was no covariance that took place between the structural disturbances in this study. Hence, the model parameters that are estimated in this study were 77 . Therefore, the sample size for this study was $770(77 \times 10)$. Nevertheless, the sample size collected was 387 and the ratio of sample size to model parameters that require statistical estimation was 5:1(387:77). Hence, this sample size was adequate for structural equation modelling analysis to address the research objectives.

The sampling procedure used to select 770 respondents from the target population of this study was probability sampling. A probability sampling method is one method of sampling that utilizes some form of random selection. In this study, simple random sampling was applied. This assures that each and every employee in the population had equal probability of being chosen as a respondent.

\subsection{Reliability and Validity}

Since the research instrument of this study was five-point scale, Cronbach-Alpha was applied to test the reliability of the research instrument. The Cronbach-Alpha coefficients of greater than $70 \%$ indicated that the research instrument used was reliable. The results in table 4.3 shows that the research instrument had significant reliability (internal consistency).

The validity of this study was measured using convergent and discriminant validity. The convergent validity was tested using lambda (factor loading), t-ratio, p-value, square multiple corrections, communalities, average variance extraction, and composite reliability. The results in tables 4.5 and 4.7 revealed that convergent validity was established. Furthermore, discriminant validity was tested using correlations between the constructs, factor correlation matrix and comparison between correlations square $\left(\mathrm{r}^{2}\right)$ and average variance extraction. The results in table 4.6 indicate that discriminant validity was also well established.

\subsection{Latent Variables}

The latent variables are unobserved variables which are measured by the manifest variables. The latent exogenous variables for this study were; training, supervisor support, co-worker support, and leadership while the latent endogenous variables were employee psychological empowerment and innovation. The manifest variables of each latent variable are presented in the Table 3.2 . 


\subsection{Data Analysis Procedure}

As depicted in table 3.2, the factors are measured by more than one manifest variables. Hence, the best model specification (data analysis model) that can help to address the research objectives is structural equation modelling. Prior to the application of structural equation modelling, the data was analyzed using exploratory and confirmatory factor analyses. Exploratory Factor Analysis (EFA) was used to extract factors that represent the conceptual model's construct and Confirmatory Factor Analysis (CFA) was applied to test the appropriateness of the measurement model. Subsequently, data analysis was done using structural equation modelling. Therefore, the equations that help to address the research objective were:

$$
\begin{aligned}
& \mathrm{X}_{(\mathrm{q} \times 1)}=\Lambda_{\mathrm{x}(\mathrm{q} \times \mathrm{n})} \varepsilon_{\mathrm{i}(\mathrm{n} \times 1)}+\mathrm{z}_{\mathrm{i}(\mathrm{q} \times 1)} \\
& \mathrm{Y}_{\mathrm{i}(\mathrm{p} \times 1)}=\Lambda_{\mathrm{y}(\mathrm{p} \times \mathrm{m})} \eta_{\mathrm{i}(\mathrm{m} \times 1)}+\mathrm{C}_{\mathrm{i}(\mathrm{p} \times 1)} \\
& \eta_{i(m \times 1)}=B_{(m \times m)} \eta_{i(m \times 1)}+\Gamma_{(m \times n)} \varepsilon_{i(n \times 1)}+\varsigma_{i(m \times 1)}
\end{aligned}
$$

$\mathrm{xi}(\mathrm{q} \times 1)=$ Indicators of latent exogenous variables

yi $(p \times 1)=$ Indicators of latent endogenous variables

$\Lambda \mathrm{y}(\mathrm{p} \times \mathrm{m})=$ Factor loadings relating indicators to latent endogenous variables

$\Lambda \mathrm{x}(\mathrm{q} \times \mathrm{n})=$ Factor loadings relating indicators to latent exogenous variables

$\eta \mathrm{i}(\mathrm{m} \times 1)=$ Latent endogenous variables

दi $(\mathrm{n} \times 1)=$ Latent exogenous variables

Ci $(\mathrm{m} \times 1)=$ Structural disturbances (errors in equations)

$\mathrm{Ci}(\mathrm{p} \times 1)=$ Measurement of errors in endogenous indicators

$z^{\mathrm{i}}(\mathrm{q} \times 1)=$ Measurement of errors in exogenous indicators

$\Gamma(m \times n)=$ Structural parameters relating latent endogenous to exogenous variables

$\mathrm{B}(\mathrm{m} \times \mathrm{m})=$ Structural parameters relating latent endogenous variables 
Table 3.2. Operationalization of the Constructs

\begin{tabular}{|c|c|}
\hline Latent Variable & Manifest Variable \\
\hline $\begin{array}{l}\text { Training } \\
\text { (Latent Exogenous variable) }\end{array}$ & $\begin{array}{l}\mathrm{X} 1=\text { Size of training budget } \\
\mathrm{X} 2=\text { Cost of training per employee } \\
\mathrm{X} 3=\text { Frequency training }\end{array}$ \\
\hline $\begin{array}{l}\text { Supervisor Support } \\
\text { (Latent Exogenous variable) }\end{array}$ & $\begin{array}{l}\text { X4 }=\text { Frequently of supervisor recognition per employee } \\
\text { X5 }=\text { Supervisor's contact time per employee } \\
\text { X6 }=\text { Employee excretion by the supervisor in decision making process }\end{array}$ \\
\hline $\begin{array}{l}\text { Co-worker Support } \\
\text { (Latent Exogenous variable) }\end{array}$ & $\begin{array}{l}\mathrm{X} 7=\text { Co-workers willingness to share their expertise } \\
\mathrm{X} 8=\text { Frequency of co-workers assistance in the work } \\
\mathrm{X} 9=\text { Encouragement of co-workers beyond the organization. }\end{array}$ \\
\hline $\begin{array}{l}\text { Leadership } \\
\text { (Latent Exogenous variable) }\end{array}$ & $\begin{array}{l}\text { X10. Idealized influence } \\
\text { X10.1 = the leader makes employees feel good to be around him/her. } \\
\text { X10.2 = complete faith in leader. } \\
\text { X10.3 = the leader makes friendship among the employees. } \\
\text { X10.4 = the leader goes beyond self- interest for the good of the group. } \\
\text { X10.5 = the leader considers ethical consequences of decisions. } \\
\text { X11. Inspirational motivation } \\
\text { X11.1 = the leader expresses with a few simple words that could be done easily } \\
\text { X11.2 = the leader provides appealing images about what can be done } \\
\text { X11.3 = the leader helps to find meaning in the work } \\
\text { X12. Intellectual stimulation } \\
\text { X12.1 = the leader enables to think about old problems in new ways } \\
\text { X12.2 = the leader provides with new ways of looking at puzzling things } \\
\text { X12.3 = the leader gets to rethink ideas that they had never questioned before } \\
\text { X13. Individualized consideration } \\
\text { X13.1 = the leader helps to develop every employee. } \\
\text { X13.2 = the leader alerts each employee how the employees are doing. } \\
\text { X13.3 = the leader gives personal attention to the employee during rejection } \\
\text { X14. Contingent reward } \\
\text { X14.1 = the leader tells what to do to be rewarded. } \\
\text { X14.2 = the leader provides recognition/rewards. } \\
\text { X14.3 = the leader call attention. } \\
\text { X15. Management - by - exception } \\
\text { X15.1 = I am satisfied when others meet agreed - upon standards. } \\
\text { X15.2 = As long as things are working, I do not try to change anything. } \\
\text { X15.3 = I tell others the standards they have to know to carry out their work. } \\
\text { X16. Laissez - faire leadership } \\
\text { X16.1 = I am content to let others continue working in the same ways always. } \\
\text { X16.2 = Whatever others want to do is ok with me. } \\
\text { X16.3 = I ask no more of others than what is absolutely essential. }\end{array}$ \\
\hline $\begin{array}{l}\text { Employee Psychological } \\
\text { Empowerment } \\
\text { (Latent endogenous variable) }\end{array}$ & $\begin{array}{l}\text { Meaning } \\
\text { I1 = The work I do is very important to me } \\
\text { I2 = My job activities are personally meaningful to me } \\
\text { I3 = The work I do is meaningful to me } \\
\text { Competence } \\
\text { I } 4 \text { = I have mastered the skills necessary for my job } \\
\text { I5 = I am confident about my ability to do my job } \\
\text { I6 = I am self-assured about my capabilities to perform my work activities } \\
\text { Self-Determination } \\
\text { I7 = I have significant autonomy in determining how } 1 \text { do my job } \\
\text { I8 = I can decide on my own how to go about doing my work } \\
\text { I9 = I have considerable opportunity for independence in my job. } \\
\text { Impact } \\
\text { I10 = My impact on what happens in my department is large. } \\
\text { I11 = I have a great deal of control over what happens in my department. } \\
\text { I12 = I have significant influence over what happens in my department. }\end{array}$ \\
\hline $\begin{array}{l}\text { Innovation } \\
\text { (Latent endogenous variable) }\end{array}$ & $\begin{array}{l}\text { Y1 }=\text { development of new ways or idea/s to achieve objectives } \\
\text { Y2 }=\text { generation of new idea } \\
\text { Y3 }=\text { generate original solutions for problems } \\
\text { Y4 }=\text { new working methods, techniques or instruments? } \\
\text { Y5 }=\text { new approached to execute task } \\
\text { Y6 }=\text { individual contribute to the implementation of your new ideas } \\
\text { Y7 }=\text { co-worker contribute to the implementation of your new ideas } \\
\text { Y8 }=\text { manager contribute to the implementation of your new ideas } \\
\text { Y9 }=\text { increase quality in the organization }\end{array}$ \\
\hline
\end{tabular}




\section{Results}

\subsection{Response Rate}

The questionnaire was administered to each of the 770 employees in MSRA firms situated within Nairobi. Out of these, 387 questionnaires were returned which makes up to $50.26 \%$ response rate. The data was collected from the lower level employees of each marketing research firms. According to Jackson (2003) SEM's sample size formula N: q (387/77 = $5: 1$ ), the sample size of this study was adequate to analyze the data using SEM. Furthermore, the Kaiser-Meyer-Olkin Measure of sampling adequacy in table 4.1 is 0.911 , which is greater than the threshold (50\%). Therefore, the response rate of $50.26 \%$ was adequate for SEM.

Table 4.1. KMO, Bartlett test

\begin{tabular}{|c|c|c|}
\hline \multicolumn{3}{|l|}{ KMO and Bartlett's Test } \\
\hline \multicolumn{2}{|c|}{ Kaiser-Meyer-Olkin Measure of Sampling Adequacy. } & .911 \\
\hline \multirow{3}{*}{ Bartlett's Test of Sphericity } & Approx. Chi-Square & 6665.030 \\
\hline & Df & 630 \\
\hline & Sig. & .000 \\
\hline
\end{tabular}

a. Determinant $=1.751 \mathrm{E}-008$

\subsection{Preliminary Analysis}

Prior to application of SEM analysis, the data was subjected to diagnostic analysis to ascertain the appropriateness of its underlying parametric characteristics for this statistical application. This entailed the parametric tests of exploratory factor analysis, and confirmatory factor analysis as presented and scientifically discussed below.

\subsubsection{Exploratory Factor Analysis}

The exploratory factor analysis test is to screen the data to establish its suitability for SEM. This was done using the Kaiser-Meyer-Olkin (KMO) measure of sampling adequacy (MSA), item correlations and partial correlations were used to assess the adequacy of the data for factor analysis. As presented in Table 4.1, the overall measure of sample adequacy (MSA) exceeded the 0.50 criterion $(\mathrm{MSA}=0.911)$, items' partial correlations were low $(<0.30)$ and the item correlations was not zero (determinant $=1.751 \mathrm{E}-008)$. Determinant greater than zero implies that the assumptions of positive definiteness are not violated. Bartlett's test of sphericity in Table 4.1 is significant (Chi-Square $=6665.030, \mathrm{df}=630, \mathrm{p}=$ 0.000) indicating existence of significant non-zero correlations among the measurement items. These results provided support that the data was appropriate for factor analysis.

To extract the factors, the researchers used maximum likelihood and promax oblique rotation method. This choice was found suitable since the underlying factors were suspected to be non-orthogonal and the factors were to be used in subsequent analysis of structural relationships. The unconstrained initial solution resulted in ten factors explaining $53.516 \%$ of the item variance. The items were found to have good communalities $(>0.50)$, however, three items were cross-loaded. The factor model was re-specified by iteratively trimming off the problematic items. The re-specified model extracted seven factors explaining $51.972 \%$ of the item variance and the items loaded cleanly onto their prior factors as shown in Table 4.2 below. 
Table 4.2. Pattern Matrix test

\begin{tabular}{|c|c|c|c|c|c|c|c|}
\hline & \multicolumn{7}{|l|}{ Factor } \\
\hline & Leadership 1 & Innovation & Empowerment 1 & Training & Empowerment 2 & Support & Leadership 2 \\
\hline $\mathrm{X} 1$ & & & & .711 & & & \\
\hline $\mathrm{X} 2$ & & & & .867 & & & \\
\hline $\mathrm{X} 3$ & & & & .557 & & & \\
\hline $\mathrm{X} 4$ & & & & & & .429 & \\
\hline $\mathrm{X} 7$ & & & .330 & & & .648 & \\
\hline $\mathrm{X} 8$ & & & & & & .716 & \\
\hline X10.4 & .490 & & & & & & \\
\hline X10.5 & .498 & & & & & & \\
\hline X11.1 & .584 & & & & & & \\
\hline $\mathrm{X} 11.2$ & .491 & & & & & & \\
\hline $\mathrm{X} 11.3$ & .768 & & & & & & \\
\hline $\mathrm{X} 12.1$ & .654 & & & & & & \\
\hline $\mathrm{X} 12.2$ & .820 & & & & & & \\
\hline $\mathrm{X} 12.3$ & .883 & & & & & & \\
\hline X13.1 & .510 & & & & & & \\
\hline $\mathrm{X} 13.2$ & .456 & & & & & & \\
\hline X14.3 & .530 & & & & & & \\
\hline $\mathrm{X} 15.2$ & & & & & & & .583 \\
\hline $\mathrm{X} 16.1$ & & & & & & & .662 \\
\hline $\mathrm{X} 10.1$ & & & & & & & .439 \\
\hline I1 & & & .487 & & & & \\
\hline $\mathrm{I} 2$ & & & .523 & & & & \\
\hline I4 & & & .619 & & & & \\
\hline I5 & & & .744 & & & & \\
\hline I6 & & & .799 & & & & \\
\hline I7 & & & & & .635 & & \\
\hline I8 & & & & & .728 & & \\
\hline I9 & & & & & .605 & & \\
\hline Y1 & & .780 & & & & & \\
\hline $\mathrm{Y} 2$ & & .799 & & & & & \\
\hline Y3 & & .841 & & & & & \\
\hline Y4 & & .797 & & & & & \\
\hline Y5 & & .708 & & & & & \\
\hline Y6 & & .641 & & & & & \\
\hline Y8 & & .718 & & & & & \\
\hline
\end{tabular}

Extraction Method: Maximum Likelihood.

Rotation Method: Promax with Kaiser Normalization.

a.Rotation converged in 8 iterations.

To assess the degree of internal consistency of the manifest variables, Cronbach's alpha coefficient was used. As seen in table 4.3 the alpha coefficients exceeded 0.70 except leadership 2. Leadership 2 was excluded from the further structural equation modelling analysis. Hence, the reliability of these findings indicated that there was good internal consistency. Therefore, the research instrument had good reliability.

Table 4.3. Reliability Test

\begin{tabular}{ll}
\hline Variables & Cronbach's Test Results \\
\hline Training & 0.742 \\
Support & 0.727 \\
Leadership 1 & 0.897 \\
Leadership 2 & 0.536 \\
Empowerment 1 & 0.840 \\
Empowerment 2 & 0.707 \\
Innovation & 0.908 \\
\hline
\end{tabular}

Once the above data screening tests were satisfactorily carried out, data was subjected to measurement model test using confirmatory factor analysis. The results are presented and scientifically discussed below.

4.2.2 Confirmatory Factor Analysis

Confirmatory factor analysis starts by testing whether the data fit a hypothesized measurement model or not. Subsequently, this tool helps to identify which manifest variables should be retained and which ones to be removed from further SEM analysis using uni-dimensionality test. Twenty-four manifest variables (X4, X5, X6, X9, X10.1, X10.2, $\mathrm{X} 10.3$, X10.5, X11.1, X13.3, X14.1, X14.2, X15.1, X15.2, X15.3, X16.1, X16.2, X16.3, I3, I10, I11, I12, Y7 and Y9) 
were removed from further analysis because they did not significantly represent their construct. Then, the measurement model fit was tested and the results in Table 4.4 revealed that the adjusted chi-square confirmed that the data fits the measurement model because CMIN/DF is between 2 and 5. Likewise, the values of incremental fit index (IFI) and comparative fit index (CFI) were greater than threshold, which was 0.90. The value of Root Mean Square Error of Approximation (RMSEA) was less the threshold, 0.080 and RMR was also less than the threshold, 0.050 . Therefore, the data fitted well to measurement model.

Table 4.4. Measurement Model Fit

\begin{tabular}{llllll}
\hline Model & NPAR & CMIN & DF & P & CMIN/DF \\
\hline Default model & 93 & 1008.228 & 468 & .000 & 2.154 \\
Saturated model & 561 & .000 & 0 & & \\
Independence model & 33 & 6191.999 & 528 & .000 & 11.727 \\
Model & RMR & GFI & AGFI & PGFI & \\
Default model & .050 & .863 & .835 & .720 & \\
Saturated model & .000 & 1.000 & & & \\
Independence model & .234 & .266 & .220 & .251 & \\
Model & NFI & RFI & IFI & TLI & CFI \\
& Delta1 & rho1 & Delta2 & rho2 & \\
Default model & .837 & .816 & .906 & .892 & .905 \\
Saturated model & 1.000 & & 1.000 & & 1.000 \\
Independence model & .000 & .000 & .000 & .000 & .000 \\
Model & RMSEA & LO 90 & HI 90 & PCLOSE & \\
Default model & .055 & .050 & .059 & .048 & \\
Independence model & .167 & .163 & .170 & .000 & \\
\cline { 1 - 3 }
\end{tabular}

Furthermore, square multiple correlations were analyzed to assess the extent to which the dependent variable is explained by the independent variables after X4, X5, X6, X9, X10.1, X10.2, X10.3, X10.5, X11.1, X13.3, X14.1, X14.2, X15.1, $\mathrm{X} 15.2, \mathrm{X} 15.3, \mathrm{X} 16.1, \mathrm{X} 16.2, \mathrm{X} 16.3$, I3, I10, I11, I12, Y7 and Y9 were removed. The threshold for the square multiple correlation was $20 \%$. This further helped to identify which manifest variables should be retained for further analysis and which have to be removed. Table 4.5 showed that all the manifest variables are statistically significant.

Table 4.5 demonstrated that the factor loadings are greater than 0.695 , which implies that the manifest variables were significant indicators of the constructs. However, the study requires further investigation for discriminant validity and convergent validity to proceed to structural model fit test in order to address the research objectives correctly.

Table 4.5. Regression Weights and SMC for the Measurement Model

\begin{tabular}{|c|c|c|c|c|c|c|c|c|}
\hline & & & \multicolumn{4}{|c|}{ Unstandardized Regression } & \multirow{3}{*}{$\begin{array}{l}\text { SR } \\
\text { Estimate } \\
.754\end{array}$} & \multirow{3}{*}{$\begin{array}{l}\text { SMC } \\
\text { Estimate } \\
.569\end{array}$} \\
\hline & & & Estimate & S.E. & C.R. & $\mathrm{P}$ & & \\
\hline Y1 & $<---$ & Innovation & .737 & .044 & 16.698 & $* * *$ & & \\
\hline Y2 & $<---$ & Innovation & .828 & .050 & 16.736 & $* * *$ & .756 & .571 \\
\hline Y3 & $<---$ & Innovation & .865 & .049 & 17.812 & $* * *$ & .790 & .624 \\
\hline Y4 & $<---$ & Innovation & .836 & .049 & 16.983 & $* * *$ & .764 & .583 \\
\hline Y5 & $<---$ & Innovation & 1.000 & & & & .827 & .685 \\
\hline Y6 & $<---$ & Innovation & .765 & .048 & 15.793 & $* * *$ & .724 & .524 \\
\hline Y8 & $<--$ & Innovation & .783 & .048 & 16.160 & $* * *$ & .736 & .542 \\
\hline $\mathbf{X} 3$ & $<--$ & Training & 689 & .069 & 9.937 & $* * *$ & .569 & .323 \\
\hline $\mathbf{X} 2$ & $<---$ & Training & 1.000 & & & & .888 & .788 \\
\hline $\mathbf{X} 1$ & $<--$ & Training & .730 & .064 & 11.326 & $* * *$ & .676 & .456 \\
\hline X14.3 & $<--$ & Leadership1 & .848 & .072 & 11.820 & $* * *$ & .605 & .366 \\
\hline X13.2 & $<--$ & Leadership1 & .614 & .054 & 11.328 & $* * *$ & .582 & .338 \\
\hline X13.1 & $<---$ & Leadership1 & .846 & .059 & 14.224 & $* * *$ & .715 & .511 \\
\hline X12.3 & $<---$ & Leadership1 & .961 & .069 & 13.979 & $* * *$ & .704 & .495 \\
\hline X12.2 & $<--$ & Leadership 1 & 1.000 & & & & .767 & .588 \\
\hline X12.1 & $<--$ & Leadership1 & .833 & .059 & 14.162 & $* * *$ & .631 & .399 \\
\hline X11.3 & $<--$ & Leadership1 & .959 & .064 & 15.046 & $* * *$ & .751 & .564 \\
\hline X11.2 & $<--$ & Leadership1 & .758 & .060 & 12.678 & $* * *$ & .645 & .416 \\
\hline X10.4 & $<--$ & Leadership1 & .848 & .063 & 13.551 & $* * *$ & .685 & .469 \\
\hline I1 & $<--$ & Empowerment1 & .979 & .077 & 12.785 & $* * *$ & .730 & .533 \\
\hline I2 & $<---$ & Empowerment1 & .979 & .091 & 11.775 & $* * *$ & .712 & .507 \\
\hline I4 & $<---$ & Empowerment1 & .812 & .082 & 12.847 & $* * *$ & .784 & .615 \\
\hline I5 & $<---$ & Empowerment 1 & .884 & .065 & 15.026 & $* * *$ & .702 & .493 \\
\hline I6 & $<--$ & Empowerment 1 & 1.000 & & & & .680 & .462 \\
\hline I7 & $<---$ & Empowerment 2 & .795 & .077 & 10.302 & $* * *$ & .647 & .418 \\
\hline I8 & $<--$ & Empowerment2 & .892 & .086 & 10.352 & $* * *$ & .651 & .424 \\
\hline $\mathbf{I 9}$ & $<--$ & Empowerment 2 & 1.000 & & & & .719 & .516 \\
\hline X8 & $<--$ & Support & 1.000 & & & & .692 & .479 \\
\hline$\times 7$ & $<---$ & Support & 0.898 & .106 & 12.519 & $* * *$ & .887 & .786 \\
\hline
\end{tabular}


$\mathrm{SR}=$ Standardized Regression and SMC $=$ Square Multiple Correlations

Based on CFA and EFA tests, discriminant validity of this study was established as showed in Table 4.6 because the correlations between the contracts were less than 0.60 . Besides, the correlations square was less than the average variance extraction. This implies that the four constructs of this study were measuring different things. Hence discriminant validity of this study was well established.

Table 4.6. Discriminant Validity Test Based on EFA and CFA Correlations

\begin{tabular}{|c|c|c|c|c|c|c|c|c|}
\hline Correlations & & & $\begin{array}{l}\text { CFA } \\
\text { Estimate }(r)\end{array}$ & $\begin{array}{l}\text { EFA } \\
\text { Estimate }\end{array}$ & $r^{2}$ & $\mathrm{AVE}_{\mathrm{i}}$ & $\mathrm{AVE}_{\mathrm{j}}$ & $\begin{array}{l}\text { Discriminant } \\
\text { Validity }\end{array}$ \\
\hline Innovation & $\langle--\rangle$ & Training & .337 & .301 & .1136 & .651 & .599 & Established \\
\hline Innovation & $\langle--\rangle$ & Leadership & .538 & 472 & 2894 & 651 & 692 & Established \\
\hline Innovation & $\langle--\rangle$ & Empowerment1 & .384 & .231 & .1475 & .651 & .762 & Established \\
\hline Innovation & $<-->$ & Empowerment 2 & .546 & .499 & .2981 & .651 & .648 & Established \\
\hline Training & $\langle--\rangle$ & Leadership & .537 & .492 & .2884 & .599 & .692 & Established \\
\hline Training & $\langle-->$ & Empowerment1 & .301 & .139 & .0906 & .599 & .762 & Established \\
\hline Training & $\langle-->$ & Empowerment 2 & .351 & .426 & .1232 & .599 & .648 & Established \\
\hline Leadership & $\langle--\rangle$ & Empowerment1 & .524 & .374 & .2746 & .692 & .762 & Established \\
\hline Leadership & $\langle-->$ & Empowerment 2 & .620 & .579 & .3844 & .692 & .648 & Established \\
\hline Empowerment 1 & $\langle-->$ & Empowerment2 & .548 & .192 & .3003 & .762 & .648 & Established \\
\hline Training & $\langle-->$ & Support & .162 & .267 & .0262 & .599 & .599 & Established \\
\hline Leadership & $<-->$ & Support & .461 & .489 & .2125 & .692 & .893 & Established \\
\hline Innovation & $\langle-->$ & Support & .332 & .351 & .1102 & .651 & .893 & Established \\
\hline Empowerment1 & $\langle-->$ & Support & .668 & .372 & .4462 & .762 & .893 & Established \\
\hline Empowerment 2 & $\langle-->$ & Support & .312 & .410 & .0973 & .648 & .893 & Established \\
\hline
\end{tabular}

$\mathrm{CFA}=$ Confirmatory factor analysis. EFA = Exploratory factor analysis, and AVA = Average variance extraction

The convergent validity of this study was tested using the regression weights of the factor loadings, average variance extraction and composite reliability. The factor loading in table 4.5 and average variance extraction in table 4.7 were greater than 0.50 . This implies that convergent validity is established. Besides, the composite reliability was greater than the threshold, which is 0.70 and therefore, the convergent validity of this study was also established.

Table 4.7. Convergent validity test

\begin{tabular}{llll}
\hline & Average Variance Extraction & Composite Convergent & Validity Reliability \\
\hline Training & 0.598722 & 0.884793 & Established \\
Support & 0.893385 & 0.969241 & Established \\
Leadership & 0.692318 & 0.972444 & Established \\
Empowerment 1 & 0.762063 & 0.965432 & Established \\
Empowerment 2 & 0.648217 & 0.906938 & Established \\
Innovation & 0.651160 & 0.959041 & Established \\
\hline
\end{tabular}

Since all the above analyses provided satisfactory results, the data was subjected to structural equation modelling test to address the research objectives. However, the procedure required for valid results to be obtained is that the data has to be subjected to structural equation model fit test before estimating the regression weights between latent exogenous and endogenous variables.

\subsection{Structural Model Test}

The structural model fit was tested by adjusted chi-square, incremental fit index (IFI), Tucker Lewis index (TLI), comparative factor index (CFI), Root Mean Square Error of Approximation (RMSEA) and RMR. The recommended threshold is the same as stated above in the confirmatory factor analysis. The results in table 4.8 indicated that the data fitted with the structural equation modelling. 
Table 4.8. Measurement Model Fit

\begin{tabular}{llllll}
\hline Model & NPAR & CMIN & DF & P & CMIN/DF \\
\hline Default model & 72 & 751.763 & 363 & .000 & 2.071 \\
Saturated model & 435 & .000 & 0 & & \\
Independence model & 29 & 5616.517 & 406 & .000 & 13.834 \\
Model & RMR & GFI & AGFI & PGFI & \\
Default model & .046 & .878 & .853 & .732 & \\
Saturated model & .000 & 1.000 & & & \\
Independence model & .253 & .262 & .209 & .245 & \\
Model & NFI & RFI & IFI & TLI & CFI \\
& Delta1 & rho1 & Delta2 & rho2 & .925 \\
Default model & .866 & .850 & .926 & .917 & 1.000 \\
Saturated model & 1.000 & & 1.000 & & .000 \\
Independence model & .000 & .000 & .000 & .000 & \\
Model & RMSEA & LO 90 & HI 90 & PCLOSE & \\
Default model & .053 & .047 & .058 & .200 & \\
Independence model & .182 & .178 & .187 & .000 & \\
\cline { 1 - 2 } Lasly, & &
\end{tabular}

Lastly, the relationships between latent exogenous and endogenous variables were interpreted using unstandardized regression weights at 5\% level of significance from Tables 4.9 and 4.10 . The interpretation is the same as the factor loading in measurement model above except SEM mainly focuses on the relationship between constructs.

\subsection{Relationship between Organizational Climate, Employee Psychological Empowerment and Innovation}

Based on the results in Table 4.9, all the assessed manifest variables had a positive significant effect on their construct. This Table further elaborates that the manifest variables of the employee psychological empowerment was divided into two constructs, namely, empowerment 1 and empowerment 2. Empowerment 1 entails about employees' psychological empowerment based on the meaning they put on their work and their competence. However, empowerment 2 elaborates the employee psychological empowerment based on their self-determination.

Furthermore, Table 4.9 revealed that leadership had a positive statistically significant effect to both employee psychological empowerments $(\mathrm{P}=000)$. For employees to feel empowered, they need to feel their job is important and meaningful not only to them but to the organization. Employee feel competent to perform their job owing to the skills mastery and confidence which further gives them self-assurance. Such a climate is created by the leaders. From the several leadership qualities tested in the instrument, it was found that most of the qualities earlier validated to describe transformational leadership filtered randomly to influence the outcome of employee empowerment in MSRFs with exception of reward consideration which described reward contingent. Majorly, it was found that the leaders idealized quality of going beyond self-interest for the good of the group and expressing issues with a few simple words of what staff could and should do empowers the staff at MSRFs. MSRFs leaders also inspire staff with appealing images about what staff can do and helps them to find meaning in their work. The ability of these leaders to stimulate the staff intellectually to think about old problems in new ways as the leaders provide them with new ways of looking at puzzling things is empowering. These leaders inspire staff to rethink ideas that they had never question before. The leaders help the employees to develop themselves and they individually consider employee and let them know how they are working. They reward employees by paying attention to their achievements. The findings harmonized with the findings of Berraies, Chaher and Yahia (2014), Çakar and Ertürk (2010), Ertürk (2012), Helms (2006) and Muindi (2011). The findings of this study were also in line with the theory of transformational leadership.

Table 4.10 depicts that transformational leadership was similarly found to have significant effect on employee innovations $(\mathrm{P}=0.003)$. Employees felt that the leader influence their creative abilities to generate new ideas. These leaders support the employees' efforts in the development of new ways or ideas to achieve objectives of the organization. Employees are able to generate original solutions for problems in the organization which include searching new working methods, techniques or instruments. The leaders' help employees track any new ideas they generate and encourage co-worker participation to the implementation of the new ideas fronted. Such leadership support concurs with the transformational leadership theory which holds that this leadership is measurable in terms of the leader influence to the followers and can be used to predict follower's behaviour and performance outcomes (Bass, 1985). Transformational leadership behaviours, characterized by individualized consideration and motivation, anchored on the leader's vision and values contribute to a culture that facilitates employee innovation (Elenkov \& Manev, 2005; Nutt, 2002). The findings also concurred with the findings of Damanpour and Schneider (2006). Phills et al. (2008) also stated that leaders influence social innovations involving the creation of new business models that can meet the needs of underserved populations more efficiently, effectively, and if not profitably, at least sustainably. The specific leadership behaviours may influence innovation through compliance as part of the organizational culture. Leaders who increase in centralization hindered 
innovations.

The results in Table 4.9 shows that workplace support had a positive significant effect on empowerment $1(\mathrm{P}=0.000)$ but insignificant effect on empowerment $2(\mathrm{P}=0.504)$. This implies that the workplace support, which generates from the managers and co-workers enhanced the meaning to employees' work and it improves employees' competence. Hence, it is directly proportional to the employees' psychological empowerment. A workplace climate where employees feel that their job is important and valued by the organization, they feel empowered. This means that employee job competence and meaning significantly empowers them. However, workplace support did not enhance employees' self-determination. This is because when the employees feel a workplace climate that does not support their freedom and autonomy on their job, or does not support co-workers to help them, may result to a feeling of powerlessness, which can reduce their self-determination to innovate.

Table 4.10 describes that workplace support had insignificant effect on innovation $(\mathrm{P}=0.247)$. The workplace supports that make the employees to be innovative in generating new ideas and implementing them is not yet effective. Consequently, the organizational climate based on workplace support in MSRFs did not have significant effect to innovation because the workplace support is not yet conducive to the employees. The findings did not support a previous study that found employees' innovative behaviour depends greatly on their interaction with others in the workplace (Anderson et al., 2004).

Table 4.9 shows that training support had insignificant effect on both employee psychological empowerments $(\mathrm{P}>0.05)$. The findings imply that adequacy of training budget, the cost of training per employee and frequency of trainings in MSRFs showed insignificant influence on employee feeling that training makes their job meaningful and important to the organization they work for. Besides, the training offered to the employees does not make them feel self-determined to generate new ideas or technique in work methods. This might be the quality and quantity of training offered to the employees of MSRFs could be low standard. Moreover, the training might not match the requirements or expectations of the employees. On the other hand, the training offered might not be able to help them to have adequate knowledge, skills, abilities and interest to develop new ideas, methods and approaches to make their work easy. Employee in this industry feel that they do not have autonomy and independence to set their own work schedules or have their co-workers support them to execute new ideas. This has left them disinterested with departmental activities and achievements which could further affect innovations at MSRFs negatively. Consequently, Table 4.10 presented that training had insignificant impact on innovation $(\mathrm{P}=0.255)$. The findings were inconsistent with the componential theory that postulate that creativity and innovation is dependent on the level of expertise (skills, training and knowledge), environment he/she is operating, particularly social environment (personality) and the intrinsic motivation (Bass, 1985). The findings also differed with that of Sieczka (2011) who found that offering training opportunities to workers reduces misunderstandings which may stifle creativity and innovation. The findings did not harmonize with that of Patterson, West, Shackleton and Dawson (2005) who found that employees' willingness to train and acquire knowledge enable companies to improve innovation capabilities. Therefore, the insignificant result in this study could be due to low standard of training, inadequate manifest variables of training, or lack of autonomy and independence at MSRFs which according to a previous study by Jafari and Iranzadeh (2013) found critical for training support to result to innovation.

Based on the mediating effect in Table 4.9, both employee psychological empowerments have significant effect on innovation $(\mathrm{P}<0.05)$. However, using both direct and indirect effect in Table 4.10, empowerment 1 had insignificant effect on innovation $(p=.761)$ but empowerment 2 has significant effect on innovation $(P=0.000)$. The results were consistent with the recommendation by researchers who pointed out that employee empowerment is a critical factor for innovation (Brunetto, Farr-Wharton, \& Shacklock 2007; Ertürk, 2012; Fernandez \& Moldogaziev, 2013). Similarly, Berraies, Chaher, and Yahia (2014) found employee empowerment has a positive effect on trust, innovation and organizational performance. However, the results were inconsistent with Kmieciak et al. (2012) who in their study concluded that empowerment did not affect the company's ability to innovate. Besides, another study by Jung et al. (2003) contrasted this study by revealing that this managerial practice has a negative effect on organizational innovation. 
Table 4.9. Regression Weights for the Indirect Effect

\begin{tabular}{|c|c|c|c|c|c|c|c|c|}
\hline & & & \multicolumn{4}{|c|}{ Unstandardized Regression } & \multirow{2}{*}{$\begin{array}{l}\text { SR } \\
\text { Estimate }\end{array}$} & \multirow[t]{2}{*}{ SMC } \\
\hline & & & Estimate & S.E. & C.R. & $\mathrm{P}$ & & \\
\hline Empowerment1 & $<---$ & Training & .069 & .045 & 1.521 & .128 & .089 & \\
\hline Empowerment1 & $<---$ & Support & .395 & .057 & 6.954 & $* * *$ & .501 & .513 \\
\hline Empowerment1 & $<---$ & Leadership & .258 & .056 & 4.606 & $* * *$ & .311 & \\
\hline Empowerment 2 & $<---$ & Training & .031 & .054 & .574 & .566 & .040 & .466 \\
\hline Empowerment 2 & $<---$ & Support & .031 & .046 & .669 & .504 & .039 & \\
\hline Empowerment2 & $<---$ & Leadership & .539 & .071 & 7.642 & $* * *$ & .645 & \\
\hline Innovation & $<---$ & Empowerment 1 & .198 & .077 & 2.567 & .010 & .147 & .356 \\
\hline Innovation & $<---$ & Empowerment 2 & .698 & .095 & 7.355 & $* * *$ & .524 & \\
\hline Y1 & $<---$ & Innovation & .738 & .045 & 16.533 & $* * *$ & .752 & .566 \\
\hline Y2 & $<---$ & Innovation & .830 & .050 & 16.588 & $* * *$ & .754 & .568 \\
\hline Y3 & $<---$ & Innovation & .866 & .049 & 17.625 & $* * *$ & .788 & .621 \\
\hline Y4 & $<---$ & Innovation & .840 & .050 & 16.895 & $* * *$ & .764 & .584 \\
\hline Y5 & $<---$ & Innovation & 1.000 & & & & .825 & .680 \\
\hline Y6 & $<---$ & Innovation & .765 & .049 & 15.625 & $* * *$ & .721 & .520 \\
\hline Y8 & $<---$ & Innovation & .786 & .049 & 16.052 & $* * *$ & .736 & .541 \\
\hline $\mathbf{X 3}$ & $<---$ & Training & .694 & .070 & 9.970 & $* * *$ & .571 & .326 \\
\hline $\mathbf{X} 2$ & $<---$ & Training & 1.000 & & & & .884 & .782 \\
\hline $\mathbf{X} 1$ & $<---$ & Training & .735 & .065 & 11.361 & $* * *$ & .678 & .459 \\
\hline I1 & $<---$ & Empowerment 1 & .909 & .072 & 12.658 & $* * *$ & .733 & .537 \\
\hline I2 & $<---$ & Empowerment1 & 1.000 & & & & .719 & .517 \\
\hline I4 & $<---$ & Empowerment1 & .959 & .083 & 11.507 & $* * *$ & .773 & .598 \\
\hline I5 & $<---$ & Empowerment1 & .896 & .074 & 12.069 & $* * *$ & .698 & .487 \\
\hline I6 & $<---$ & Empowerment 1 & .914 & .078 & 11.738 & $* * *$ & 677 & .458 \\
\hline I7 & $<---$ & Empowerment 2 & .755 & .077 & 9.751 & $* * *$ & .611 & .373 \\
\hline I8 & $<---$ & Empowerment 2 & .871 & .087 & 10.003 & $* * *$ & .632 & .399 \\
\hline I9 & $<---$ & Empowerment 2 & 1.000 & & & & .719 & .516 \\
\hline X14.3 & $<---$ & Leadership & .828 & .070 & 11.761 & $* * *$ & .599 & .358 \\
\hline X13.2 & $<---$ & Leadership & .597 & .053 & 11.222 & $* * *$ & .574 & .329 \\
\hline X13.1 & $<---$ & Leadership & .821 & .058 & 14.101 & $* * *$ & .703 & .494 \\
\hline X12.3 & $<---$ & Leadership & .958 & .067 & 14.305 & $* * *$ & .712 & .507 \\
\hline $\mathrm{X} 12.2$ & $<---$ & Leadership & 1.000 & & & & .778 & .605 \\
\hline X12.1 & $<---$ & Leadership & .816 & .058 & 14.094 & $* * *$ & .627 & .393 \\
\hline X11.3 & $<---$ & Leadership & .951 & .062 & 15.321 & $* * *$ & .755 & .570 \\
\hline X11.2 & $<---$ & Leadership & .746 & .059 & 12.754 & $* * *$ & .644 & .414 \\
\hline X10.4 & $<---$ & Leadership & .829 & .061 & 13.555 & $* * *$ & .679 & .461 \\
\hline X8 & $<---$ & Support & .634 & .065 & 9.696 & $* * *$ & .640 & .410 \\
\hline $\mathbf{X 7}$ & <--- & Support & 1.000 & & & & .972 & .945 \\
\hline
\end{tabular}

Table 4.10 depicts for both direct, indirect, and total effect. Moreover, it helps to assess the effectives of the mediating effect of employee psychological empowerment on the relationship between organizational climates on innovation. The employee psychological empowerment had partial mediating effect when calculated using Sobel test (Sobel, 1982) as presented in tables 4.10 and 4.11 . 
Table 4.10. Regression Weights for both Direct and Indirect Effect

\begin{tabular}{|c|c|c|c|c|c|c|c|c|}
\hline & & & \multicolumn{4}{|c|}{ Unstandardized Regression } & \multirow{2}{*}{$\begin{array}{l}\mathbf{S R} \\
\text { Estimate }\end{array}$} & \multirow[t]{2}{*}{ SMC } \\
\hline & & & Estimate & S.E. & C.R. & $\mathrm{P}$ & & \\
\hline Empowerment1 & $<--$ & Training & .068 & .045 & 1.502 & .133 & .088 & \\
\hline Empowerment1 & $<---$ & Support & .399 & .057 & 6.993 & $* * *$ & .502 & .509 \\
\hline Empowerment1 & $<---$ & Leadership & .254 & .056 & 4.544 & $* * *$ & .306 & \\
\hline Empowerment2 & $<---$ & Training & .019 & .058 & .333 & .739 & .024 & \\
\hline Empowerment2 & $<---$ & Support & .029 & .049 & .590 & .555 & .035 & .402 \\
\hline Empowerment2 & $<---$ & Leadership & .523 & .073 & 7.160 & $* * *$ & .607 & \\
\hline Innovation & $<---$ & Empowerment1 & .031 & .101 & .304 & .761 & .023 & \\
\hline Innovation & $<--$ & Empowerment2 & .402 & .105 & 3.839 & $* * *$ & .309 & \\
\hline Innovation & $<---$ & Training & .075 & .066 & 1.139 & .255 & .072 & .362 \\
\hline Innovation & $<---$ & Support & .081 & .070 & 1.157 & .247 & .076 & \\
\hline Innovation & $<---$ & Leadership & .298 & .100 & 2.968 & .003 & .266 & \\
\hline Y1 & $<--$ & Innovation & .738 & .044 & 16.650 & $* * *$ & .754 & .568 \\
\hline $\mathrm{Y} 2$ & $<---$ & Innovation & .830 & .050 & 16.697 & $* * *$ & .755 & .571 \\
\hline Y3 & $<---$ & Innovation & .867 & .049 & 17.784 & $* * *$ & .791 & .625 \\
\hline Y4 & $<---$ & Innovation & .838 & .049 & 16.964 & $* * *$ & .764 & .584 \\
\hline Y5 & $<--$ & Innovation & 1.000 & & & & .826 & .683 \\
\hline Y6 & $<---$ & Innovation & .766 & .049 & 15.750 & $* * *$ & .724 & .523 \\
\hline Y8 & $<---$ & Innovation & .785 & .049 & 16.136 & $* * *$ & .737 & .543 \\
\hline $\mathrm{X} 3$ & $<---$ & Training & .688 & .069 & 9.953 & $* * *$ & .568 & .323 \\
\hline $\mathrm{X} 2$ & $<--$ & Training & 1.000 & & & & .888 & .788 \\
\hline $\mathrm{X} 1$ & $<--$ & Training & .731 & .064 & 11.367 & $* * *$ & .676 & .457 \\
\hline I1 & $<---$ & Empowerment1 & .905 & .072 & 12.634 & $* * *$ & .731 & .535 \\
\hline $\mathrm{I} 2$ & $<---$ & Empowerment1 & 1.000 & & & & .720 & .519 \\
\hline I4 & $<--$ & Empowerment1 & .959 & .083 & 11.513 & $* * *$ & .775 & .600 \\
\hline I5 & $<--$ & Empowerment1 & .895 & .074 & 12.080 & $* * *$ & .699 & .488 \\
\hline I6 & $<---$ & Empowerment1 & .915 & .078 & 11.770 & $* * *$ & .679 & .461 \\
\hline I7 & $<--$ & Empowerment2 & .735 & .076 & 9.698 & $* * *$ & .614 & .377 \\
\hline I8 & $<--$ & Empowerment2 & .870 & .086 & 10.100 & $* * *$ & .651 & .424 \\
\hline I9 & $<---$ & Empowerment2 & 1.000 & & & & .741 & .550 \\
\hline $\mathrm{X} 14.3$ & $<---$ & Leadership & .827 & .070 & 11.791 & $* * *$ & .599 & .359 \\
\hline $\mathrm{X} 13.2$ & $<--$ & Leadership & .597 & .053 & 11.242 & $* * *$ & .574 & .329 \\
\hline $\mathrm{X} 13.1$ & $<---$ & Leadership & .819 & .058 & 14.125 & $* * *$ & .703 & .494 \\
\hline $\mathrm{X} 12.3$ & $<---$ & Leadership & .959 & .067 & 14.372 & $* * *$ & .713 & .509 \\
\hline $\mathrm{X} 12.2$ & $<---$ & Leadership & 1.000 & & & & .779 & .607 \\
\hline $\mathrm{X} 12.1$ & $<---$ & Leadership & .818 & .058 & 14.154 & $* * *$ & .630 & .397 \\
\hline X11.3 & $<---$ & Leadership & .946 & .062 & 15.295 & $* * *$ & .753 & .567 \\
\hline $\mathrm{X} 11.2$ & $<---$ & Leadership & .742 & .058 & 12.717 & $* * *$ & .641 & .411 \\
\hline $\mathrm{X} 10.4$ & $<---$ & Leadership & .829 & .061 & 13.599 & $* * *$ & .680 & .462 \\
\hline $\mathrm{X} 8$ & $<--$ & Support & .639 & .065 & 9.796 & $* * *$ & .643 & .413 \\
\hline $\mathrm{X7}$ & $<---$ & Support & 1.000 & & & & .968 & .937 \\
\hline
\end{tabular}

Table 4.11 further depicts the statistical significance of the mediation effect of employee psychological empowerment using the Sobel test (Sobel, 1982). The results in table 4.11 revealed that employee psychological empowerment mediated the relationship between leadership and innovation only. The type of mediation effect was partial mediation because both the direct and indirect effects are significant as presented in table 4.10.

Table 4.11. Indirect effect test

\begin{tabular}{llll}
\hline Mediation Effect of Employee Psychological Empowerment & Z-Calculate & Z-Critical & Significance of indirect effect \\
\hline Training - empowerment 1 - innovation & 0.264 & \pm 1.96 & Insignificant \\
Training - empowerment 2 - innovation & 0.316 & \pm 1.96 & Insignificant \\
Support - empowerment 1- innovation & 0.304 & \pm 1.96 & Insignificant \\
Support - empowerment 2- innovation & 0.318 & \pm 1.96 & Insignificant \\
Leadership - empowerment 1- innovation & 0.306 & \pm 1.96 & Insignificant \\
Leadership - empowerment 2 - innovation & 3.351 & \pm 1.96 & Significant \\
\hline
\end{tabular}

\section{Conclusion}

This study has yielded a high empirical validity for its theoretical model that was to establish the relationship between organizational climate, employee psychological empowerment and innovations. The findings supported transformational leadership and the intrinsic motivation theories. In tandem with transformational leadership theories, it was found that 
transformational leadership is the most salient factor influence both employee empowerment and innovation despite many scholars avoiding inclusion transformational leadership in their studies of relationship between organizational climate and innovations citing that it is hard to measure, self-promotional and hard to train. The findings concurred with the transformational theory in that MSRFs operate in unstable business environments that previous scholars found to favor transformational leadership to thrive. From this result it is therefore suspect that exclusion of transformational leadership in the previous studies of organizational climate and innovation relationship might have caused the inconsistent results reported. The study strongly supports the theory of transformational leadership and call for scholars to consider this very important variable as a climate factor and test its influence in other industries or sectors to verify our finding and accord its generalization.

Similarly, intrinsic motivation theory was supported by the study results. The theory proposed states that, an individual is intrinsically motivated to behave in a certain way when he feels internally rewarded by the behavior chosen. Intrinsic motivation is driven by self-desire to seek out new things and new challenges, to analyze individual's capacity, to observe and acquire knowledge. From this study, employees who felt intrinsically motivated had self-determination which significantly influenced their innovative behavior at MSRFs in Kenya. This theory of intrinsic motivation holds that self-determination founded on competence, autonomy and relatedness innate empowered employees to optimally function and grow. This concurred with the finding that employee who had self-determination driven by autonomy and independence influenced innovation. It was found that employees' who did not have self-determination but had competences and meaningful jobs did not feel empowered to innovate. This means empowerment may have enhanced self-determination for them to innovate. This therefore made the researcher suspect that omission of employee empowerment to mediate innovation and organizational climate could have as well yielded the varied results on influence of and innovation. The researcher may therefore call other scholars to test this mediating effect of employee empowerment in similar studies using more factors to verify the finding to generalize to other sectors.

It was also found workplace support from leaders and supervisors who strengthened their competences and designed meaningful jobs empowered employees but did not affect their determination which is innate. This again put workplace support critical to drive a feeling of competent and their job importance which can reduce with absence of this support.

This concurs with the transformational leadership theory where the leader influences employee's behavior and feelings. This verify where many scholars have considered workplace support in the studies of organizational climate and into predict employee feelings and behavior.

Although training support empirically fitted very well as organizational climate variables based on cost, frequency and size of the budget it had insignificant effect on both psychological empowerment and innovation in MSRFs in Kenya just as was hypothesized. This contrasted with the componential theory which hold that skills, training and knowledge determine innovativeness of employees. This made the researchers suspect why training might have been left out in many studies of organizational climate and innovation. This may call for inclusion of more indicators of training support to verify the true position of impact of training support on innovation. Scholars and researchers may incorporate other variables like autonomy and independence which other scholars in the past had found critical to influence training outcomes.

The study indicated there could be a positive relationship between organizational climate, employees' psychological empowerment and innovation. It was found that the mediating variable (employee psychological empowerment) had partial effect between OC and innovation. This is a finding that has not been fronted by other scholars in the past. Future studies may need to incorporate other factors to explore the mediation effect of psychological empowerment between organizational climate and innovation given that scholars have concurred that organizations can sustainably remain afloat if only employees are innovative.

\section{References}

Alice, H. Y. H., \& Steven, S. L. (2016). Employee creativity and innovation in organizations: Review, integration, and future directions for hospitality research. International Journal of Contemporary Hospitality Management, 28(5), 862-885. https://doi.org/10.1108/IJCHM-09-2014-0454

Alice, L. (2011). Innovative Organizations: Structure, Learning and Adaptation. Paper presented at the DIME Final Conference, 6-8 April 2011, Maastricht. 162-177.

Amabile, T. M. (1996). Creativity in context. Boulder, CO: Westview Press.

Amabile, T. M., \& Khaire, M. (2008). Creativity and the role of the Leader. Harvard Business Review, 86, 100-109. https://doi.org/10.1177/02750740022064560

Anderson, N., Carsten, K. W., De Dreu, \& Bernard, A. (2004). The routinization of innovation research: a constructively critical review of the state-of-the-science. Organizational Behaviour, 25(2), 147-173. https://doi.org/10.1002/job.236 
Angle, H. A. (1989). Psychology and organizational innovation. In A. Van de Ven, H. Angle, \& M. S. Poole (Eds.), Research on the management of innovation: The Minnesota studies. New York: Ballinger. 135-170

Antonakis, J., \& House, R. J. (2014). Instrumental leadership: Measurement and extension of transformationaltransactional leadership theory. The Leadership Quarterly, 25, 746-777. https://doi.org/10.1016/j.leaqua.2014.04.005

Antonakis, J., Cianciolo, A. T., \& Sternberg, R. J. (2004). The nature of leadership. Thousand Oaks, CA: Sage. appropriate sample size for survey research", 19(1).

Arora, V., \& Kamalanabhan, T. J. (2013). Linking supervisor and coworker support to employee.

Ashforth, B. E. (1989). The experience of powerlessness in organizations. Organizational Behavior and Human Decision Processes, 43, 207-242. https://doi.org/10.1016/0749-5978(89)90051-4

Bandura, A. (1989). A social cognitive theory of action. In J. P. Forgas \& M. J. Innes (Eds.), Recent advances in social psychology: An international perspective. North Holland: Elsevier, 127-138.

Bartlett, J. E., Kotrlik, J. W., \& Higgins, C. (2001). "Organizational research: Determining Appropriate Sample Size in Survey Research. Information Technology, Learning, and Performance Journal, 19(1), 43-50.

Bass, B. M. (1985). Leadership and performance beyond expectations. New York, NY: The Free

Batey, M. (2012). The Measurement of Creativity: From Definitional Consensus to the Introduction of a New Heuristic Framework. Psychometrics at Work Research Group, Manchester Business School-creativity research journal, 24(1), 55-65. https://doi.org/10.1080/10400419.2012.649181

Bell, N. E., \& Staw, B. M. (1989). People as sculptors versus sculpture: The roles of personality and personal control in organizations. In: Arthur MB, Hall DT, Lawrence BS, editors. Handbook of career theory. New York: Cambridge University Press, pp. 232-251.

Alice, H. Y. H., \& Steven, S. L. (2016). Employee creativity and innovation in organizations: Review, integration, and future directions for hospitality research. International Journal of Contemporary Hospitality Management, 28(5), 862-885. https://doi.org/10.1108/IJCHM-09-2014-0454

Alice, L. (2011). Innovative Organizations: Structure, Learning and Adaptation. Paper presented at the DIME Final Conference, 6-8 April 2011, Maastricht. 162-177.

Amabile, T. M. (1996). Creativity in context. Boulder, CO: Westview Press.

Amabile, T. M., \& Khaire, M. (2008). Creativity and the role of the Leader. Harvard Business Review, 86, 100-109. https://doi.org/10.1177/02750740022064560

Anderson, N., Carsten, K. W., De Dreu, \& Bernard, A. (2004). The routinization of innovation research: a constructively critical review of the state-of-the-science. Organizational Behaviour, 25(2), 147-173. https://doi.org/10.1002/job.236

Angle, H. A. (1989). Psychology and organizational innovation. In A. Van de Ven, H. Angle, \& M. S. Poole (Eds.), Research on the management of innovation: The Minnesota studies. New York: Ballinger. 135-170

Antonakis, J., \& House, R. J. (2014). Instrumental leadership: Measurement and extension of transformationaltransactional leadership theory. The Leadership Quarterly, 25, 746-777. https://doi.org/10.1016/j.leaqua.2014.04.005

Antonakis, J., Cianciolo, A. T., \& Sternberg, R. J. (2004). The nature of leadership. Thousand Oaks, CA: Sage. appropriate sample size for survey research", 19(1).

Arora, V., \& Kamalanabhan, T. J. (2013). Linking supervisor and coworker support to employee.

Ashforth, B. E. (1989). The experience of powerlessness in organizations. Organizational Behavior and Human Decision Processes, 43, 207-242. https://doi.org/10.1016/0749-5978(89)90051-4

Bandura, A. (1989). A social cognitive theory of action. In J. P. Forgas \& M. J. Innes (Eds.), Recent advances in social psychology: An international perspective. North Holland: Elsevier, 127-138.

Bartlett, J. E., Kotrlik, J. W., \& Higgins, C. (2001). "Organizational research: Determining Appropriate Sample Size in Survey Research. Information Technology, Learning, and Performance Journal, 19(1), 43-50.

Bass, B. M. (1985). Leadership and performance beyond expectations. New York, NY: The Free

Batey, M. (2012). The Measurement of Creativity: From Definitional Consensus to the Introduction of a New Heuristic Framework. Psychometrics at Work Research Group, Manchester Business School-creativity research journal, 
24(1), 55-65. https://doi.org/10.1080/10400419.2012.649181

Bell, N. E., \& Staw, B. M. (1989). People as sculptors versus sculpture: The roles of personality and personal control in organizations. In: Arthur MB, Hall DT, Lawrence BS, editors. Handbook of career theory. New York: Cambridge University Press, pp. 232-251.

Berraies, S., Chaher, M., \& Yahia, K. B. (2014). Employee empowerment and its importance for trust, innovation and organizational performance. Business Management and Strategy, 5(2), 82-103. https://doi.org/10.5296/bms.v5i2.6558

Boso, N., Cadogan, J. W., \& Story, V. M. (2013). Entrepreneurial orientation and market orientation as drivers of product innovation success: A study of exporters from a developing economy. International Small Business Journal, 31(1), 57-81. https://doi.org/10.1177/0266242611400469

Brief, A., \& Nord, W. (1990). Meanings of Occupational Work: A Collection of Essays. Lexington, MA: Lexington Books.

Brunetto, Y., Farr, W., \& Shacklock, K. H. (2007). Comparing the impact of management.

Burns, J. M. (1978). Leadership. New York: Harper \& Row.

Çakar, N. D., \& Ertürk, A. (2010). Comparing innovation capability of small and medium sized capability: evidence from SMEs. Industrial Management and Data Systems, 112(5), 707-728. https://doi.org/10.1108/02635571211232280

Carmeli, A., \& Spreitzer, G. M. (2009). Trust, Connectivity, and Thriving: Implications for Innovative Behaviors at Work. 43(3), 169-191. https://doi.org/10.1002/j.2162-6057.2009.tb01313.x

Choi, H. S., \& Thompson, L. L. (2006). Creativity and Innovation in Organizational Teams. eBook. ISBN: 9781410615732.

Damanpour, F., \& Schneider, M. (2006). Phases of the adoption of innovation in organizations: Effects of environment, organization, and top managers. British Journal of Management: 17, 215. https://doi.org/10.1111/j.1467-8551.2006.00498.x

Deci, E. L., \& Ryan, R. M. (1985). Intrinsic Motivation and Self-Determination in Human Behavior.

Deci, E. L., Connell, J. P., \& Ryan, R. M. (1989). Self-determination in a work organization.

Dodds, R. A., Smith, S. M., \& Ward, T. B. (2002). The use of environmental clues during incubation. Creativity Research Journal, 14, 287-305. https://doi.org/10.1207/S15326934CRJ1434_1

Dul, \& Ceylun, (2011). Work environments for employee creativity. 2011 Jan. 54(1), 12-20. https://doi.org/10.1080/00140139.2010.542833

Ekvall, G. (1996). Organizational climate for creativity and innovation. European Journal of Work

Elenkov, D. S., \& Manev, I. M. (2005). Top Management Leadership and Influence on Innovation: Examining the effects of organizational culture and empowerment. Journal of Small Business Management, 48(3), 325-359.

Ertürk, A. (2012). Linking Psychological Empowerment to Innovation Capability: Investigating the Moderating Effect of Supervisory Trust. International Journal of Business and Social Science, (3)14, 153-165.

Eustace, A., \& Martins, N. (2014). The role of leadership in shaping organizational climate: An example from the fast-moving consumer goods industry-SA Journal of Industrial Psychology; 40(1), 13 pages. https://doi.org/10.4102/sajip.v40i1.1112

Fernandez, S., \& Moldogaziev, T. (2013). Using employee empowerment to encourage innovative behavior in the public sector. Journal of Public Administration Research and Theory, 23, 155-187.

Furnham, A., Batey, M., Anand, K., \& Manfield, J. (2008). Personality, hypomania, intelligence and creativity. Personality and Individual Differences, 44, 1060-1069. https://doi.org/10.1016/j.paid.2007.10.035

George, J. M., \& Zhou, J. (2007). Dual tuning in a supportive context: Joint contributions of positive mood, negative mood, and supervisory behaviors to employee creativity. Academy of Management Journal, 50, 605-622. https://doi.org/10.5465/AMJ.2007.25525934

Gist, M. E. (1987). Self-efficacy: Implications for organizational behavior and human resource management. Academy of Management Review, 12, 472-485

Govindarajan, V., \& Trimble, C. (2010). Leadership, Innovation and Entrepreneurship: What leadership capabilities are necessary to support innovation and entrepreneurship?

Hackman, J. R., \& Oldham, G. R. (1980) Work redesign. Readings, MA: Addison-Wesley. 
Helms, M. M. (2006). Encyclopedia of management (5th ed.). Thomson Gale, USA.

Hsiu, F. L. (2007). Effects of extrinsic and intrinsic motivation on employee knowledge sharing intention. Journal of Information Science. https://doi.org/10.1177/0165551506068174

Hunter, S. K., Critchlow, A., \& Enoka, R. M. (2004). Influence of aging on sex differences in muscle fatigability. $J$ Appl Physiol, 97, 1723-1732. https://doi.org/10.1152/japplphysiol.00460.2004

Hunter, S. T., Bedell, K. E., \& Mumford, M. D. (2007). Climate for creativity: A quantitative review. Creativity Research Journal, 19, 69-90. https://doi.org/10.1080/10400410709336883

Jackson, D. L. (2003). Revisiting sample size and number of parameter estimates: Some support for the N:q hypothesis. Structural Equation Modeling: A Multidisciplinary Journal, 10(1), 128-141.

Jafari, S., \& Iranzade, I. (2013). The Relationship between Empowerment and Organizational Citizenship Behavior. International Journal of Basic Sciences \& Applied Research, 2(10), 903-907.

Jung, D. I., Chow, C., \& Wu, A. (2003). The role of transformational leadership in enhancing.

Kahreh, M. S., \& Heidar, A. H. (2011). Achieving competitive advantage through empowering.

Khan, S. (1997). The key to being a leader company: empowerment. Journal for Quality and Participation, 44-50.

Kmieciak, R., Michna, A., \& Meczynska, A. (2012). Innovativeness, empowerment and IT.

Lawrence Erlbaum Associates - Business and Economics. Management of Innovation: The Minnesota Studies, A. Van de Ven, H. Angle, and M. S. Poole, eds. New York: Ballinger/Harper \& Row.

Michael, E. S. (1982). Asymptotic confidence intervals for indirect effects in structural equation models. Sociological Methodology, 13, 290-312. https://doi.org/10.2307/270723

Moye, J., \& Henkin, B. (2006). Exploring associations between employee empowerment and interpersonal trust in managers. Journal of Management Development, 25(2) ,101-117. https://doi.org/10.1108/02621710610645108

Muindi, F. K. (2011). The relationship between participation in decision making and job satisfaction among academic staff in the school of business, university of Nairobi. Journal of Human Resource Management Research. https://doi.org/10.5171/2011.246460

Mumford, M. D. (2003). Where have we been, where are we going? Taking stock in creativity research. Creativity Research Journal, 15, 107-120. https://doi.org/10.1080/10400419.2003.9651403

Muturi, O., \& Douglas. (2015). Organizational Climate and Readiness for Change to Lean Six Sigma for Kenya Institute of management (KIM).

Ndanuko, M. W. (2012). Relationship between school organizational climate and pupil's academic performance among public primary schools in Nairobi province, Kenya Need Theories. Retrieved from Wiki Spaces: ttps://wikispaces.psu.edu/display/PSYCH484/2.+Need+Theories

Nijstad, B. A., \& Stroebe, W. (2006). "How the group affects the mind: A cognitive model of idea generation in groups. Personality and Social Psychology Review, 10: 186-213. https://doi.org/10.1207/s15327957pspr1003_1

Non-profit Organization.

Nutt, P. C. (2002). Why decisions fail: Avoiding the blunders and traps that lead to debacles. San Francisco: Berrett-Koehler.

Nyhan, R. C. (2000). Changing the Paradigm: Trust and its Role in Public Sector Organizations.

Nystrom, P. C., Ramamurthy, K., \& Wilson, A. L. (2002). Organizational context, climate and organizational innovation: hypotheses and some preliminary findings. Leadership Quarterly, 14, 525-544.

Patterson, M. G., et al. (2005). Validating the organizational climate measure: Links to managerial practices, productivity and innovation. Journal of Organizational Behavior, 26, 379-408. https://doi.org/10.1002/job.312

Phills, J. A. Jr., Deiglmeier, K., \& Miller, D. T. (2008). Rediscovering social innovation. Stanford practices on public sector nurses' and administrative employees' commitment to the organisation. Asian Pacific Journal of Health Management, 2(1), 17-34.

Purohit, B., \& Wadhwa, A. (2012). "Organisational Climate from view point of Motivation in District Hospital, India", Health, 4(7), 400-406. https://doi.org/10.4236/health.2012.47063

Runco, M. A. (2004). Creativity. Annual Review of Psychology 55,657-687. Science, 3(14). https://doi.org/10.1146/annurev.psych.55.090902.141502 
Shalley, C. E., Gilson, L. L., \& Blum, T. C. (2009). Interactive effects of growth need strength, work context, and job complexity on self-reported creative performance. Academic of Management, 52(3), 489-505. https://doi: 10.5465/AMJ.2009.41330806

Shalley, C. E., Zhou, J., \& Greg, R. O. (2004). The Effects of Personal and Contextual Characteristics on Creativity: Where Should We Go from Here.

Shin, S. J., \& Zhou, J. (2003). Transformational leadership, conservation, and creativity: Evidence from Korea. Academy of Management Journal, 46, 703-714.

Sieczka, K. (2011). Cause and Effect: Barriers to Creativity and Innovation. Social Innovation Review, Fall, 35-42

Spreitzer, G. M. (1995). Psychological empowerment in the workplace, dimensions. Measurements and validation. Journal of academy of management, 38(5), 1442-1465. https://doi.org/10.2307/256865

Thomas, K. B., \& Velthouse, B. A. (1990). Cognition elements of empowerment: an "interpretive" work context, and job complexity on self-reported creative performance. Academy of Management Journal, 52, 489-505.

Wanberg, C. R., \& Banas. J. T. (2000). Predictors and Outcomes of Openness to Changes in a Reorganizing Workplace. Journal of Applied Psychology, (85)1, 132-142. https://doi.org/10.1037/0021-9010.85.1.132

Berraies, S., Chaher, M., \& Yahia, K. B. (2014). Employee empowerment and its importance for trust, innovation and organizational performance. Business Management and Strategy, 5(2), 82-103. https://doi.org/10.5296/bms.v5i2.6558

Boso, N., Cadogan, J. W., \& Story, V. M. (2013). Entrepreneurial orientation and market orientation as drivers of product innovation success: A study of exporters from a developing economy. International Small Business Journal, 31(1), 57-81. https://doi.org/10.1177/0266242611400469

Brief, A., \& Nord, W. (1990). Meanings of Occupational Work: A Collection of Essays. Lexington, MA: Lexington Books.

Brunetto, Y., Farr, W., \& Shacklock, K. H. (2007). Comparing the impact of management.

Burns, J. M. (1978). Leadership. New York: Harper \& Row.

Çakar, N. D., \& Ertürk, A. (2010). Comparing innovation capability of small and medium sized capability: evidence from SMEs. Industrial Management and Data Systems, 112(5), 707-728. https://doi.org/10.1108/02635571211232280

Carmeli, A., \& Spreitzer, G. M. (2009). Trust, Connectivity, and Thriving: Implications for Innovative Behaviors at Work. 43(3), 169-191. https://doi.org/10.1002/j.2162-6057.2009.tb01313.x

Choi, H. S., \& Thompson, L. L. (2006). Creativity and Innovation in Organizational Teams. eBook. ISBN: 9781410615732.

Damanpour, F., \& Schneider, M. (2006). Phases of the adoption of innovation in organizations: Effects of environment, organization, and top managers. British Journal of Management: 17, 215. https://doi.org/10.1111/j.1467-8551.2006.00498.x

Deci, E. L., \& Ryan, R. M. (1985). Intrinsic Motivation and Self-Determination in Human Behavior.

Deci, E. L., Connell, J. P., \& Ryan, R. M. (1989). Self-determination in a work organization.

Dodds, R. A., Smith, S. M., \& Ward, T. B. (2002). The use of environmental clues during incubation. Creativity Research Journal, 14, 287-305. https://doi.org/10.1207/S15326934CRJ1434_1

Dul, \& Ceylun, (2011). Work environments for employee creativity. 2011 Jan. 54(1), 12-20. https://doi.org/10.1080/00140139.2010.542833

Ekvall, G. (1996). Organizational climate for creativity and innovation. European Journal of Work

Elenkov, D. S., \& Manev, I. M. (2005). Top Management Leadership and Influence on Innovation: Examining the effects of organizational culture and empowerment. Journal of Small Business Management, 48(3), 325-359.

Ertürk, A. (2012). Linking Psychological Empowerment to Innovation Capability: Investigating the Moderating Effect of Supervisory Trust. International Journal of Business and Social Science, 3(14), 153-165.

Eustace, A., \& Martins, N. (2014). The role of leadership in shaping organizational climate: An example from the fast-moving consumer goods industry-SA Journal of Industrial Psychology; 40(1), 13 pages. https://doi.org/10.4102/sajip.v40i1.1112

Fernandez, S., \& Moldogaziev, T. (2013). Using employee empowerment to encourage innovative behavior in the public sector. Journal of Public Administration Research and Theory, 23, 155-187. https://doi.org/10.1093/jopart/mus008 
Furnham, A., Batey, M., Anand, K., \& Manfield, J. (2008). Personality, hypomania, intelligence and creativity. Personality and Individual Differences, 44, 1060-1069. https://doi.org/10.1016/j.paid.2007.10.035

George, J. M., \& Zhou, J. (2007). Dual tuning in a supportive context: Joint contributions of positive mood, negative mood, and supervisory behaviors to employee creativity. Academy of Management Journal, 50, 605-622. https://doi.org/10.5465/AMJ.2007.25525934

Gist, M. E. (1987). Self-efficacy: Implications for organizational behavior and human resource management. Academy of Management Review, 12, 472-485

Govindarajan, V., \& Trimble, C. (2010). Leadership, Innovation and Entrepreneurship: What leadership capabilities are necessary to support innovation and entrepreneurship?

Hackman, J. R., \& Oldham, G. R. (1980) Work redesign. Readings, MA: Addison-Wesley.

Helms, M. M. (2006). Encyclopedia of management (5th ed.). Thomson Gale, USA.

Hsiu, F. L. (2007). Effects of extrinsic and intrinsic motivation on employee knowledge sharing intention. Journal of Information Science. https://doi.org/10.1177/0165551506068174

Hunter, S. K., Critchlow, A., \& Enoka, R. M. (2004). Influence of aging on sex differences in muscle fatigability. J Appl Physiol, 97, 1723-1732. https://doi.org/10.1152/japplphysiol.00460.2004

Hunter, S. T., Bedell, K. E., \& Mumford, M. D. (2007). Climate for creativity: A quantitative review. Creativity Research Journal, 19, 69-90. https://doi.org/10.1080/10400410709336883

Jackson, D. L. (2003). Revisiting sample size and number of parameter estimates: Some support for the N:q hypothesis. $\begin{array}{lllll}\text { Structural Equation Modeling: A Multidisciplinary Journal, } & 10(1), & 128-141 .\end{array}$ https://doi.org/10.1207/S15328007SEM1001_6

Jafari, S., \& Iranzade, I. (2013). The Relationship between Empowerment and Organizational Citizenship Behavior. International Journal of Basic Sciences \& Applied Research, 2(10), 903-907.

Jung, D. I., Chow, C., \& Wu, A. (2003). The role of transformational leadership in enhancing.

Kahreh, M. S., \& Heidar, A. H. (2011). Achieving competitive advantage through empowering.

Khan, S. (1997). The key to being a leader company: empowerment. Journal for Quality and Participation, 44-50.

Kmieciak, R., Michna, A., \& Meczynska, A. (2012). Innovativeness, empowerment and IT.

Lawrence Erlbaum Associates - Business and Economics. Management of Innovation: The Minnesota Studies, A. Van de Ven, H. Angle, and M. S. Poole, eds. New York: Ballinger/Harper \& Row.

Michael, E. S. (1982). Asymptotic confidence intervals for indirect effects in structural equation models. Sociological Methodology, 13, 290-312. https://doi.org/10.2307/270723

Moye, J., \& Henkin, B. (2006). Exploring associations between employee empowerment and interpersonal trust in managers. Journal of Management Development, 25(2), 101-117. https://doi.org/10.1108/02621710610645108

Muindi, F. K. (2011). The relationship between participation in decision making and job satisfaction among academic staff in the school of business, university of Nairobi. Journal of Human Resource Management Research. https://doi.org/10.5171/2011.246460

Mumford, M. D. (2003). Where have we been, where are we going? Taking stock in creativity research. Creativity Research Journal, 15, 107-120. https://doi.org/10.1080/10400419.2003.9651403

Muturi, O., \& Douglas, (2015). Organizational Climate and Readiness for Change to Lean Six Sigma for Kenya Institute of management (KIM).

Ndanuko, M. W. (2012). Relationship between school organizational climate and pupil's academic performance among public primary schools in Nairobi province, Kenya Need Theories. Retrieved from Wiki Spaces: ttps://wikispaces.psu.edu/display/PSYCH484/2.+Need+Theories

Nijstad, B. A., \& Stroebe, W. (2006). "How the group affects the mind: A cognitive model of idea generation in groups. Personality and Social Psychology Review, 10: 186-213. https://doi.org/10.1207/s15327957pspr1003_1

Non-profit Organization.

Nutt, P. C. (2002). Why decisions fail: Avoiding the blunders and traps that lead to debacles. San Francisco: Berrett-Koehler.

Nyhan, R. C. (2000). Changing the Paradigm: Trust and its Role in Public Sector Organizations. 
Nystrom, P. C., Ramamurthy, K., \& Wilson, A. L. (2002). Organizational context, climate and organizational innovation: hypotheses and some preliminary findings. Leadership Quarterly, 14, 525- 544.

Patterson, M. G., et al. (2005). Validating the organizational climate measure: Links to managerial practices, productivity and innovation. Journal of Organizational Behavior, 26, 379-408. https://doi.org/10.1002/job.312

Phills, J. A. Jr., Deiglmeier, K., \& Miller, D. T. (2008). Rediscovering social innovation. Stanford practices on public sector nurses' and administrative employees' commitment to the organisation. Asian Pacific Journal of Health Management, 2(1), 17-34.

Purohit, B., \& Wadhwa, A. (2012). "Organisational Climate from view point of Motivation in District Hospital, India", Health, 4(7), 400-406. https://doi.org/10.4236/health.2012.47063

Runco, M. A. (2004). Creativity. Annual Review of Psychology 55,657-687. Science, 3(14). https://doi.org/10.1146/annurev.psych.55.090902.141502

Shalley, C. E., Gilson, L. L., \& Blum, T. C. (2009). Interactive effects of growth need strength, work context, and job complexity on self-reported creative performance. Academic of Management, 52(3), 489-505. https://doi.org/10.5465/AMJ.2009.41330806

Shalley, C. E., Zhou, J., \& Greg, R. O. (2004). The Effects of Personal and Contextual Characteristics on Creativity: Where Should We Go from Here.

Shin, S. J., \& Zhou, J. (2003). Transformational leadership, conservation, and creativity: Evidence from Korea. Academy of Management Journal, 46, 703-714. https://doi.org/10.2307/30040662

Sieczka, K. (2011). Cause and Effect: Barriers to Creativity and Innovation. Social Innovation Review, Fall, 35-42

Spreitzer, G. M. (1995). Psychological empowerment in the workplace, dimensions. Measurements and validation. Journal of academy of management, 38(5), 1442-1465. https://doi.org/10.2307/256865

Thomas, K. B., \& Velthouse, B. A. (1990). Cognition elements of empowerment: an "interpretive" work context, and job complexity on self-reported creative performance. Academy of Management Journal, 52, 489-505.

Wanberg, C. R., \& Banas. J. T. (2000). Predictors and Outcomes of Openness to Changes in a Reorganizing Workplace. Journal of Applied Psychology, (85)1, 132-142. https://doi.org/10.1037/0021-9010.85.1.132

\section{Copyrights}

Copyright for this article is retained by the author(s), with first publication rights granted to the journal.

This is an open-access article distributed under the terms and conditions of the Creative Commons Attribution license which permits unrestricted use, distribution, and reproduction in any medium, provided the original work is properly cited. 